\title{
Linkages Between Financial Market Development and Economic Growth in Ethiopia
}

\author{
Ephrem Ahadu \\ Lecturer at Wachemo university, Ethiopia
}

\begin{abstract}
In this study we consider the link between financial development and economic growth from 1971 to 2009 in Ethiopia. Most theoretical and empirical works in the literature suggest that deeper financial market promotes economic growth. We take this hypothesis to the test of conducting descriptive and empirical study using Ethiopia's data. In the empirical analysis we estimate an investment equation applying the Stock Watson Dynamic OLS procedure. The result suggests that the financial development indicator positively and significantly explains investment suggesting that financial development and economic growth have direct and strong relationship. The argument that financial development and economic growth have positive linkages is supported by results of both descriptive and empirical analysis. But the argument that financial development determines economic growth appears to be inconclusive. The Granger causality test result suggests bidirectional influence between financial development and economic growth.
\end{abstract}

Keywords: Financial,Market,Development,Growth

DOI: $10.7176 / \mathrm{JEP} / 10-22-01$

Publication date: August $31^{\text {st }} 2019$

\section{INTRODUCTION}

Exploring the link between financial development and economic growth has been the focus of academics, policy makers and economists. Despite a wide controversy as to how financial markets contribute to economic growth, there seems consensus now on the roles financial markets play in promoting economic growth. But there is no consensus on whether structure of the financial system was important for economic growth. Financial markets regardless of the structure facilitate the working of efficient payment systems, mobilization of savings and the allocation of funds to productive investment channels.

According to the theory of financial repression, financial markets play little role in economic growth. This is happened since the financial sector is over regulated and characterized by ceilings in interest rates and government interventions in credit allocation to priority sectors. In this regard, the advice is to adopt financial liberalization because it improves the efficiency of financial intermediation, channels more funds to productive sectors and increase national savings. Specifically, when interest rate is positive in real terms, it increases financial savings and encourages investment.

The financial system plays a pivotal role in an economy intermediating between lenders and borrowers, providing a menu of saving vehicles with deferring risks and helping investors find financing needs. Financial intermediaries also reduce costs to both savers and borrowers and help reduce problems of asymmetric information that are inherent between savers and entrepreneurs. They also enhance investment by reducing liquidity risks. Sophisticated derivative instruments help improve the allocation of risk in the economy and increase efficiency of the savings/investment process. For a given level of savings a more efficient financial intermediation increases the productivity of investment. It thus seems that the more efficient the financial system the more rapid economic growth would be.

A large body of theoretical and recent empirical literatures suggest that deeper, broader and better functioning financial market stimulate higher economic growth (Levine, Loayzz, King, Eck). Ndikumana (2003) studied the role of financial intermediaries in economic growth and found that they affect economic growth positively and significantly. Other studies such as Robinson argue that financial development passively follows economic growth by responding to the increasing demand for funds triggered by prosperity. The debate on the causality of financial development and growth is still on today. Understanding the role of financial markets in economic development and their causation continues to attract the attention of academics and policy makers. It is particularly important for developing countries to design appropriate polices.

Exploring the linkages between financial development and economic growth requires addressing two empirical questions: These are verifying whether financial development leads to higher economic growth and identifying the channels through which financial intermediaries affect economic activities. This paper aims at elucidating the linkage between financial development and economic growth as well as testing their causality in the case of Ethiopia. While Ethiopiae s financial sector has not been studded to any great extent, this study is also believed to narrow the gap in the literature. The study uses both descriptive analyses and empirical investigation by estimating an investment equation to show the importance of financial development to enhance investment or real economic activities. The Stock - Watson Dynamic OLS procedure is applied in the empirical study. 
This paper is organized as follows. Section two gives review of macroeconomic and financial sector developments of the Ethiopian economy. Theoretical and empirical literatures are reviewed in section three. Descriptive analysis of the linkages of financial development and economic growth and empirical analysis are given in sections four and five. The paper also provides brief conclusion.

\section{MACROECONOMIC AND FINANCIAL SECTOR OVERVIEW Economic Performance}

Rebounding from the 2002/03 drought, there has been strong economic growth in Ethiopia over the past seven years. According to official data, annual real GDP growth in the past six years averaged $11.5 \%$ which is much higher than the Sub-Saharan African average of about $6 \%$. Despite the global economic crises, economic growth during 2008/09 was $9.9 \%$ and growth in 2009/10 is estimated to be $10.1 \%$. Ethiopia has had a string of good harvests which in turn were results of good rains combined with rises in area cultivated. The bumper harvests in agricultural production underpin activities in manufacturing and services. Increased and sustained public investment in infrastructure has also enhanced economic activities. Looking at the sources of growth we observe that all sectors have revealed significant growths but the growth of the service sector was very strong

Fig.1. Depicts growth rates by economic activities namely agriculture, industry and service sectors. It shows that the growth in the service sector was very strong.

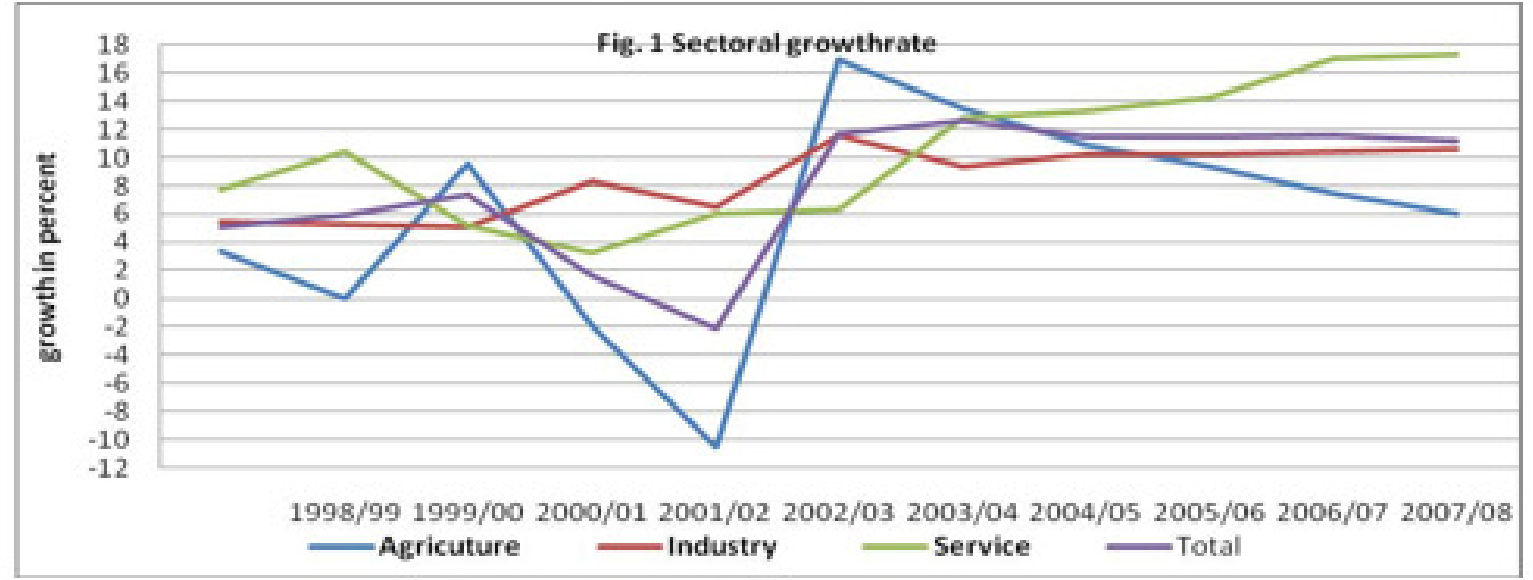

Nonetheless, Ethiopia experienced macroeconomic imbalance in 2008 and 2009. Largely owing to aggressive public investment in infrastructure and credit expansion, the inflation rate reached an historic record high of 64.2 percent in July 2008. Notwithstanding the pressure of international fuel and commodity price shocks in 2008, international reserves of the country fell to all time low of covering about five weeks of imports. The local currency Birr was overvalued. IMF staff report estimated that the local currency was overvalued by above 30 percent in June 2009.

In a bid to restore macroeconomic balance, the government has been pursuing strong policy measures. This includes among others, pursuing tighter monetary and fiscal policy stance, elimination of domestic fuel price subsidy, rationing foreign exchange to importers and significant and stepped exchange rate adjustments. As a result of these measures and good cereals harvest, inflation has sharply tumbled to single digits. General annual inflation rate in June 2010 was $7.3 \%$ and food inflation has become zero. International reserve of the country has increased significantly to a level of covering over two months of imports. The exchange rate of the birr has adequately been adjusted to increase competitiveness of exports and depress conspicuous imports. In the last few years the nominal exchange rate of the local currency against the USD has been depreciated by over $40 \%$. Currently the Birr is traded at the marginal rate of Birr 13.5 to 1USD.

\section{Financial sector development}

As part of the broader market oriented economic policy agenda, implementation of the financial sector reform begun in the early 1990s. These reforms were geared towards building a sound, competitive and well functioning financial system that supports sustainable economic growth and development. A series of financial and foreign exchange reform measures have been issued since October 1992. New banking and insurance laws have been issued in 1994. The supervisory role of the central bank was extended to cover microfinance institutions. The banking laws were amended in 2008. Anti money laundering law was also enacted in 2009.

Although its objective was to increase the role of financial markets in resource mobilization and allocation as well as providing sufficient funds to finance private and public investments, a gradual financial sector reform agenda has been pursued. Ethiopia appears to be unique in regards to prohibiting entrance of foreign banks compared to many of its neighboring counties like Kenya, Uganda, Tanzania, and many other developing countries. Moreover Ethiopiaes financial sector is characterized by dominance of state ownership and low level of 
development. Unlike in many other countries, there is clear demarcation between government and private banks that no private shares exist in state-owned banks and government has no shares in any private bank. Ethiopia's financial sector remained closed and is much less developed than its neighbors (Kiyoto etal 2007)

Ethiopia's financial sector is rudimentary and dominated by the banking system. Currently, the sector includes 16 banks, 12 insurance companies, 30 microfinance institutions, over 700 savings and credit cooperatives and a Social Security Authority. There is also unorganized active informal financial market that includes the traditional savings and lending mechanisms such as idir, equb and mahber. There is informal issuance of shares but there is no security or capital market. Many companies are established by issuing shares in the various sectors of the economy.

Money markets are not developed that there is only a thin primary market for treasury bills and weak interbank money market. Except government issued bonds, all types of capital markets including stock exchange and equity markets are non-existing. The regulatory and institutional framework for this market is not developed yet

The banking system comprises the National Bank of Ethiopia (central bank), 15 commercial banks ( 2 stateowned and 13 private), and 1 specialized state-owned bank. These banks currently have 673 branch networks all over the country. But Ethiopia remains under banked that on average over 120,000 people are served by a branch in contrast to less than 100,000 are served by one bank branch in Sub-Saharan Africa. In terms of ownership state owned banks dominate the market.

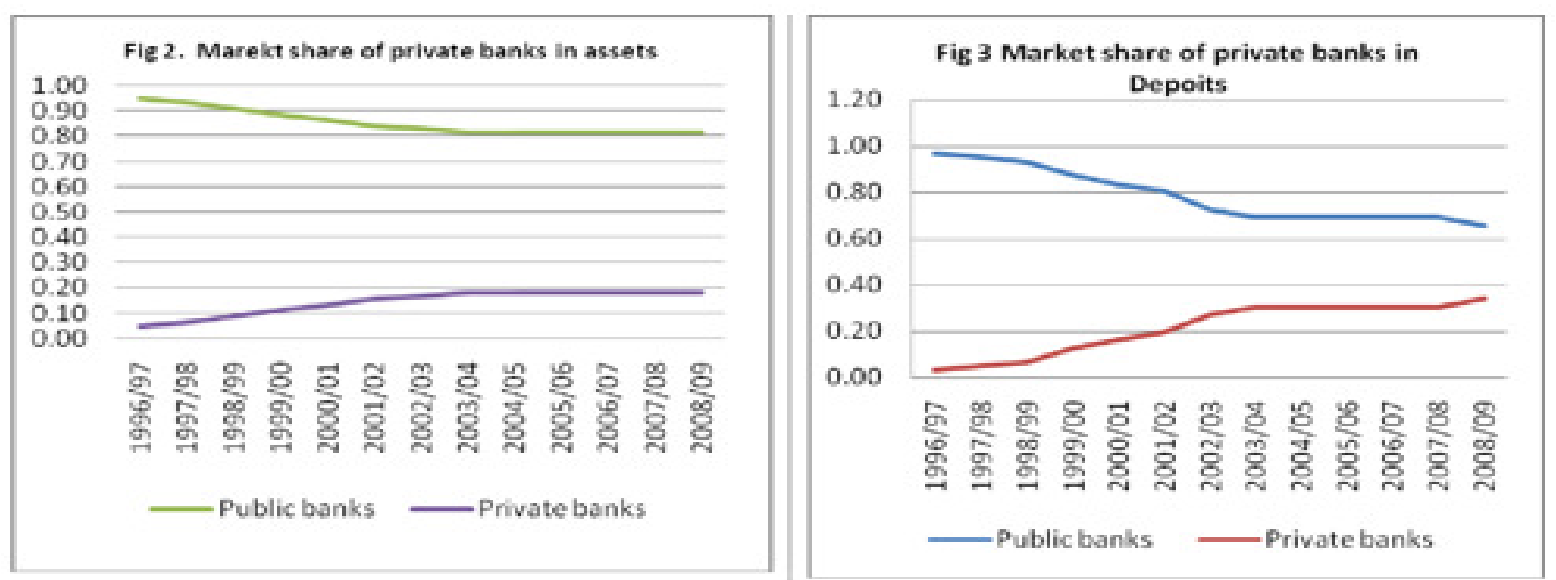

Banking service is concentrated in major cities and towns. As of June 2009 there were 241 (36\% of total) commercial bank branches in Addis Ababa only. With regard to ownership structure and concentration, the stateowned banks dominate the market. At end June 2009, public banks controlled $65.7 \%$ of loans, $64.5 \%$ of deposit liabilities, $42.9 \%$ of branch networks and $63.5 \%$ of capital. Commercial Bank of Ethiopia claims 46 percent of total banking sector capital and 33 percent of total branch networks. (NBE Reports: 2009). Assets of the banking sector increased from Birr 20 billion at June 1996 to Birr62.5 billion at June 2009.

\section{THEORETICAL AND EMPIRICAL EVIDENCES}

Huge and growing literatures exist on the link between financial development and economic growth There are two views in economic theory regarding the importance of finance for growth and economic development namely: 1) an efficient financial system is key determinant to economic growth and 2) financial sector does not mater very much that any correlation between financial development and growth is a result of growth leading development. According to the literature, exploring the linkages between financial development and economic growth requires addressing two empirical questions: These are verifying whether financial development leads to higher economic growth and identifying the channels through which financial intermediaries affect economic activities. Empirical studies have generally but not fully supported the conclusion of positive correlation between financial and economic development but failed to establish their direction of causality.

A large body of evidences exists that support the argument relating to the strong linkages between financial sector development and growth. Many theoretical and empirical works on the role of financial markets suggest positive relationship between financial development and economic growth (Khan and Senhadji 2000, Argettry, etal 1997, Kpodar 2008, Kiypta etal 2007). Walter Bagehot argued that England 's efficient capital market made the industrial revolution possible; Schumpeter contended that financial development causes economic development by channeling capital to the entrepreneurs with high return projects. It is argued that economic growth is centered at the heart of the process of capital formation which in turn depends on the availability of capital in the economy. In this regard, huge capital investment is needed for the provisions of basic infrastructural and development related facilities, particularly for developing countries. This huge investment itself is determined by domestic and foreign savings. Hence, banks play key role in mobilizing these savings and allocating the required 
capital for investment and growth.

The causation is ambiguous that in earlier period the level of economic development used to be perceived as determinant of the development of the financial market, but nowadays there is a change in this perception that real economic activities are constrained by weak financial system, implying that financial sector development is one of the pre-requisites for economic growth (Narayana: 2000), It is widely argued that a developed financial system accelerates economic development but a financial system alone is unlikely to develop without the real economy. Most studies underline on the proposition that economic growth in Sub-Saharan African countries has been hampered by weak and repressed financial systems (Aryeetey 1997).

The view that capital market is the basis for saving mobilization and economic growth is a recent development. The importance of capital market for economic growth is explained on the emphasis towards raising the rate of private domestic voluntary saving and allocates that saving more efficiently

through the development and effective use of capital markets. This is in contrast with the widely held view in the $1950^{\circ} \mathrm{s}$ and $1960^{\circ \mathrm{s}} \mathrm{s}$ which regarded foreign aid and fiscal policy as the basis for development. Some studies have also found weak relationship between financial sector development and growth.

The development of sophisticated derivates instruments has helped improve also risks in the economy and increase the efficiency of the saving investment process, implying that the more efficient the financial system means the more rapid economic growth would be. The scope and complexity of this network largely depends on the level of development of an economy.

In the 1960s Raymond Goldsmith conducted a massive cross country empirical study and demonstrated a positive correlation between financial development and economic growth. Patric (1966) studied financial sector development to growth in the early stages of development but the impact diminishes gradually as the economy develops and the impact of growth on financial sector development predominates. Robert King and Ross Levine (1993) found a positive statistically significant cornelian between GDP per head and proxies of financial development.

McKinnon and Shaw published books in 1073 showing that financial repression or holding interest rate down boosts investment and savings and hence growth. There is also a fiscal policy rationale for lower interest rate that government reduces its own borrowing costs and by forcing financial institutions to hold liquid deposits increases the benefits it drives from seignior age. They show that countries which are financially repressed are characterized by credit rationing and artificially lower real interest rates and in the 1960s financial repression and inflation shrunk the deposit base for domestic bank lending in developing countries. In addition financial repression leads to lower savings and also created a bias in favor of capital intensive investments.

Some studies have also found weak relationship between financial sector development and growth.

A study by Kpodar... etal (2008) identified both positive and negative channels through which financial development affects poverty. The positive channel is that financial development helps to reduce poverty by facilitating transactions and allowing the poor to benefit from financial services that increase their income (through interest earned) and enhance their ability to undertake profitable investments and other activities. The negative channel is that instability arises at various stages of the financial development and it undermines poverty reduction because the poor are generally more vulnerable than the rich to unstable and malfunctioning financial institutions.

A study by British Department for International Development (DFID) in 2004 found that there is a great deal of evidence to suggest that financial sector development is important for growth and poverty reduction and without it development may be held back even if other conditions are met

King and Levine (1993) find that the value of financial depth in 1960 predicts the rate of economic growth, capital accumulation and productivity improvement over the next 30 years. They also find that the relationship between the initial level of financial sector development and growth is large

Other studies find that bidirectional causation of financial development and economic growth. However the impact of financial development on growth is more important relative to the other particularly in, developing countries. This suggests that financial sector underdevelopment is more likely to hold growth back in developing countries

Barbara etal (2007) undertook a study on the Ethiopia"s banking sector and found that liberalizing restrictions on foreign bank entry accelerates the efficiency of the domestic banking sector and thereby contribute to long run economic growth. Openness in financial services had positive and significant effects on economic growth. Some studies have also found that higher government ownership of banks was associated with slower subsequent financial sector development and lower productivity growth. It is widely accepted that the private sector must be the engine of growth and that governments must work to create the right enabling environment for private sector development. By facilitating transactions and making credit, the financial sector is a crucial building block for private sector development. It also plays an important role in reducing risks and vulnerability and increasing the ability of individuals and households to access basic services like health and education thus having a more direct impact on poetry reduction. 


\section{LINKING FINANCIAL DEVELOPMENT AND GROWTH IN ETHIOPIA}

Financial markets in developed economies mainly refer to the operations of capital market that include both financial and property markets. Financial market refers to money market or short term debt markets while the property market refers to the situation of business incur debt to acquire stocks of materials or goods-in-process or to buy items like mortgage homes. The market for financial assets is well developed and efficiently operating in these economies. In developing countries like Ethiopia, where capital market is non-existing, the scope of financial market is limited to organized financial intermediaries mainly referring to banks and insurance companies. Small size of the financial sector coincide with weak legal and institutional financial infrastructure and the banking sector usually dominate the sector (Kawalec and Kluza: 2000)

At an early stage of development a country can function with a relatively unsophisticated financial system particularly if it has decent banks. Building a gleaming stock exchange in a poor country with an in-adequate legal framework and accounting practices is not going to increase the growth rate. As the economy develops the financial system becomes more sophisticated with it. The financial system should be allowed to develop more rapidly relative to per capita GDP than has been the historical norm-- that a modern financial system can increase the efficiency of investment and contribute to growth both by reducing the costs of intermediation and by improving the allocation of risk. Such a system makes it possible for some firms that cannot self finance to carry out projects that otherwise would not have taken place and this increase output. Thus a financial system should be a leader in the development process.

Financial development refers to increase in financial services, improvement in efficiency and competitiveness of financial intermediaries, the amount of money intermediated by financial institutions, diversity of financial institutions, the extent of capital allocated by private financial institutions to private sector, etc.

There are different kinds of financial development indicators. In the literature three broad categories of indicators are given. These are monetary aggregates, stock markets, and institutions and structures. In the past several years, there has been notable development in monetary aggregates and institutions in Ethiopia. Domestic liquidity measured by broad money supply increased more than threefold from Birr 29.1 billion in June 2003 to Birr 96.2 billion in March 2010. Capital of banks increased to Birr 11.1 billion in March 2010, loans and advances of commercial banks expanded from 15.1 billion in June 2000 to Birr 53.1 billion in March 2010. Services of microfinance institutions have also substantially increased in the past five years. Their lending shoot up from Birr 1.4 billion in 2003 to over five billion birr in 2009 serving over three million beneficiaries. Over $50 \%$ of beneficiaries of microfinance institutions are rural dwellers.

In regards to institutional development there are seventeen banks including NBE and Development Bank of Ethiopia as of March 2010 in contrast to only three in 1994. These banks have over 673 branch networks all over the country today compared to less than 150 branches ten years ago. The number of insurance companies and microfinance institutions reached 12 and 30, respectively from 1 insurance company and no microfinance institution in 1995

It is argued thus that financial development in Ethiopia in the past several years has contributed to the strong growth in the economy. The empirical analysis in the following section attempts to explore this linkage and causation of the growth

\section{EMPIRICAL ANALYSIS}

\section{Model, Data, Methodology and co-integration}

Both theoretical and empirical studies suggest that there is positive and significant relationship between financial development and economic growth. Country specific empirical studies have also showed that financial development directly benefit the poor and contributes to poverty reduction. But there is no consensus in the literature regarding the causality between financial development and economic growth. Whether financial development leads to higher economic growth can empirically be addressed by modeling indicators of financial development to the growth rate of per capita income or investment.

Following Ndikumana (2003) we model and estimate the following long run investment equation in the case of Ethiopia.

$$
\ln I=\not b+\not \beta \ln F I N+, 2 \ln T R A D E g+i
$$

Where I is the gross investment to GDP ratio, FIN is financial development indicator which is represented by liquid liabilities of commercial banks (demand, savings and time deposits) to GDP ratio. This gives an alternative to broad money ratio. The argument is that in developing countries the larger share of broad money is currency outside banks which reflects more extensive use of currency than increased use of deposits. We believe that it is a better measure of financial depth and overall size of financial intermediaries. TRADE is (export +import)/to GDP ratio which measures openness or degree of liberalization and $\mathrm{g}$ is real GDP Per Capita growth. A financial market policy dummy is also included in the estimated model to capture effects of policy changes and reforms. Impacts of other important variables like size of government, inflation and exchange rate are controlled in this model. 
According to economic theory all the coefficients are expected to be positive except TRADE which is empirically determined. A log linear specification model is used to represent the long run investment equation because it yields elastic ties in a convenient form and it has been well used in error correction models in several previous studies.

The study uses annual data covering the period spanning from 1971 to 2008 . The data are collected from different sources. National accounts data obtained from the Ministry of .Finance and Economic

Development reports, monetary data from annual reports of the National Bank of Ethiopia and price data from Central Statistical Agency.

\section{The Stock Watson Dynamic OLS Approach}

This dynamic OLS approach has certain advantages over the classical OLS and the Johansson Maximum Likelihood procedures. It is proposed by Stock and Watson (1993). It improves on OLS by coping with small sample and dynamic sources of bias. The Johansson method is exposed to the problem that parameter estimates on one equation are affected by any misspecification in other equations. Thus, DOLS is by contrast a robust single equation approach which corrects for regressor endogeniety by the inclusion of leads and lags of first differences of the regressors and for serially correlated errors by a GLS procedure. This method has been applied to the estimation of similar studies.

\section{Co-integration Tests}

The classical regression properties hold only for stationary or integrated of order zero variables. Most economic time series variables are however integrated of order one or I (1) and therefore do not satisfy the OLS assumptions. But where long run relationship exists certain combination of integrated of order one or I (1) variables .are likely to be integrated of zero or I (0) and hence amenable to OLS estimation. In such cases the variables used in the model are said to be co-integrated and OLS estimates of such co-integrated variables may be super consistent in adjusting to their true values more quickly than if the variables had been stationary

The first step is to determine the degree of integration of each variable included in the model. This we do using standard Dickey-Fuller (DF) and Augmented Dickey-Fuller (ADF) tests on a regression of original values. Accordingly, DF and ADF tests were used to detect stationarity of the variables included in the model. Schwarz Bayesian Criterion (SBC) and Akaike information Criterion were also used for selecting the order of argumentation. We found that the first differences of the investment, trade and financial indicator variables are I (1) and per capita income growth was I (0),

To examine co-integration between the variables included in the model we estimated the equation above in OLS. The results are reported in Table 1 below. The ADF test of the residual clearly indicates existence of cointegration. . All the coefficients have the expected signs, are highly significant and pass the standard diagnostic tests.

Table 1 OLS estimation of the investment equation

\begin{tabular}{|l|l|l|}
\hline Repressors & Coefficient (SE) & Diagnostic test (LM version (p-value) \\
\hline c & $0.023(0.170)$ & Serial correlation $0.536(0.765)$ \\
\hline LTRIN & $0.019(0.519)$ & Functional form $3.199(0.053)$ \\
\hline PCg & $0.601(0.090)$ & Normality $0.112(0,944)$ \\
\hline R2 & $0.012(0.001)$ & Heteroscdasticy $0.724(0.633)$ \\
\hline AR2 & 0.88 & \\
\hline DW stat & 0.87 & \\
\hline ADF Test Statistic & 1.65 & \\
\hline Akaike info criterion & -3.583 & \\
\hline Schwarz criterion & -0.335258 & \\
\hline
\end{tabular}




\section{Estimation of the model}

The Stock Watson Dynamic OLS approach is employed to estimate the dynamic investment equation. Given the data points, two lags and leads of the first difference of each explanatory variable were included in the estimation and insignificant ones were dropped from the model. The result is reported in table 2 below. Coefficient elasticties of long run financial indicator and trade are 0.23 and 0.178 , respectively, both are significant and born the expected sign while coefficient of per capita income growth is significant but with negative sign. This may imply increase in income leads to more consumption instead of enhancing investment. Coefficient of the dummy (DU) which captures effects of financial liberalization and policy change is significant and positively explained investment. The DOLS result is robust as indicated by the standard diagnostic tests reported in table 2 .

Thus, consistent with theory and most empirical findings, financial development and trade positively explain investment then leads to economic growth. .

Table 2 Stock -Watson DOLS estimation result of the investment equation

\begin{tabular}{|c|c|c|}
\hline Repressors & Coefficient (SE) & Diagnostic test (LM version (p-value) \\
\hline $\mathrm{c}$ & $-1.855(0.221)$ & Serial correlation $0.306(0.738)$ \\
\hline LFIN & $0.234(0.044)$ & Functional form $167.069(0.00)$ \\
\hline LTRA & $0.178(0.058)$ & Normality $0.76(0,68)$ \\
\hline $\mathrm{PCg}$ & $0.013(0.004)$ & Heteroscdasticy $0.724(0.633)$ \\
\hline DLFIN(1) & $0.252(0.094)$ & \\
\hline DLFIN(2) & $0.328(0.085)$ & \\
\hline $\operatorname{DLTRA}(1)$ & $0.341(0.081)$ & \\
\hline Dpeg & $-0.009(0.003)$ & \\
\hline $\operatorname{Dpeg}(-1)$ & $-0.008(0.002)$ & \\
\hline $\mathrm{Du}$ & $3.608(0.464)$ & \\
\hline $\mathrm{R} 2$ & 0.99 & \\
\hline AR2 & 0.98 & \\
\hline DW stat & 1.70 & \\
\hline
\end{tabular}

\section{Causality Test}

The debate is now more on the causation or direction of influence. Most empirical studies argue that financial development triggers investment and economic growth while others argue that financial play passive role to economic growth. Meanwhile other studies support bidirectional influence. Regarding causation of financial development and investment we run test of Granger causality and we obtained the following result

Table 3. Causality Test

\begin{tabular}{|l|c|c|c|}
\hline Null Hypothesis & Observation & F-Statistic & Probability \\
\hline LNFIN does not Granger Cause LNI & 37 & 2.23258 & 0.12369 \\
\hline LNI does not Granger Cause LNFIN & & 0.61596 & 0.54640 \\
\hline
\end{tabular}

Granger causality test of financial development and investment seems to suggest that causation is bidirectional. The hypothesis that argues financial development triggers economic growth appears to be disproved and causation turns out to be both directions. . 


\section{CONCLUSIONS}

The purpose of this study was to explore the linkages between financial development and economic growth using Ethiopian data. The major objective was therefore exploring whether financial development leads to economic growth or not in Ethiopia. Looking at monetary aggregates, institutions and structures as measures of financial development we observe that there has been a significant growth in financial services in Ethiopia in the past several years. Deposit liabilities of banks, number of banks and their branches, amount of loans extended by banks have all been increasing significantly. Financial intermediation increased from $13.7 \%$ in 2000 to 21.4 percent in 2009 with annual average growth rate of $14.8 \%$. The contribution of financial services to GDP has also increased from $1.8 \%$ to $2.7 \%$ in the same period. Official data also show that there has been double digit growth in real GDP. This suggests a positive link between financial development and economic growth. The empirical analysis also seems to support this that financial development indicators positively and significantly explain investment and economic growth. But the argument financial development determines growth has not been supported empirically. The empirical result seems to suggest that causation is bidirectional

Despite notable improvements and growth in financial development, financial services are still inadequate and inefficient that weakens the link between financial development and growth. A stable macroeconomic framework promotes positive relationship between financial development and growth and reduces vulnerability to financial crisis. Sound, regulatory framework; strong corporate governance, adoption of standard accounting and auditing practices help enhancing financial intermediation.

\section{REFERENCE}

$>$ Adnan, Noureen (nd) The role of the financial sector in economic growth, PhD Student University of Surrey,UK

$>$ Addison, Tony and Alemayehu Geda (2001) "Ethiopia"s financial sector and its regulation" WIDER Discussion Paper No 2001/55.

> Alfaro, Laura \{... Etal) FDI and Economic Growth: The role of Local Financial Markets (2003) Aziakpono, M.J (nd). Financial Development and Economic Growth in Southern Africa

$>$ Bhatt ,V.V. (1993), On financial sector reform and development: A case study of Ghana, in Saving and development, Quarterly review, No. 1.

$>$ DFID Financial Sector Team (2004). The Importance of Financial sector Development for Growth and Poverty Reduction

$>$ Ephraim W. Chirwa (1999), Financial sector reform in Malawi: Are days of „financial repression' gone?, in Saving and development, Quarterly review, No. 3.

$>$ Honohan, Patrick (2003). Financial Development, Growth and Poverty: How close are the links, WBGroup

$>$ Jeanneney, S.G. and Kangni Kpodar (2008) "Financial development and poverty reduction: Can there be a benefit without a cost?" IMF Working Paper WP/08/62

$>$ Kawalec, Stefan and Krzysziof Kluza (2000) challenges of Financial System Development in Transition Economies

$>$ Kiyota, Kozo , Barbara Peitsch and Robert M. Stern (2007) "The case for financial sector liberalization in Ethiopia" RESE Discussion Paper No 565

$>$ Mattina, Todd (2006) Money isn"t everything: The challenge of scaling up aid to achieve the Millennium Development Goals in Ethiopia WP/06/192

$>$ McPherson, Malcom and Tzvetana Rakovski (1999). Financial Deepening and investment $\mathrm{n}$ Africa: Evidence from Botswana and Mauritius DD paper 727

$>$ Ndikumana, Leonce (2003) Financial Development, Financial Structure and Domestic Investment: International Evidence

> Ndikumana, Leonce (2001) "Financial Markets and economic development in Africa" PERI Working Series number 17 